УДК 631.51: 632.51: 635.67

(C) 2015

Маслиёв С. В., доктор сельскохозяйственных наук

Луганский национальный университет имени Тараса Шевченко

\title{
ВЛИЯНИЕ БИОПРЕПАРАТОВ НА РОСТ, РАЗВИТИЕ И УРОЖАЙНОСТЬ САХАРНОЙ КУКУРУЗЫ
}

\section{Рецензент - доктор сельскохозяйственных наук С. В. Красненков}

Надані результати польових дослідів впливу інокуляиії насіння біопрепаратами на ріст, розвиток та врожайність гібридів цінної овочевої культури - иукрової кукурудзи. Встановлена можливість підвищення врожайності та якості продукиї за рахунок обробки насіння мікробними препаратами "Діазофіт», «КЛ-9», «Фосфоентерин» + «Діазофіт». Наведені дані по споживанню мінеральних речовин та водоспожсиванню. Рекомендовані норми застосування біопрепаратів. Наведено урожайність качанів иукрової кукурудзи. Зроблений аналіз динаміки відхилення в залежності від застосованого препарату.

Ключові слова: біопрепарати, иукрова кукурудза, ріст, розвиток, врожайність, мінеральні речовини.

Постановка проблемы. Сахарная кукуруза является ценной овощной культурой. По содержанию сухого вещества, углеводов, жира, по калорийности, а также по вкусовым качествам и питательности зерна в молочно-восковой спелости она превосходит все широко распространенные овощные культуры. Белок сахарной кукурузы содержит в значительном количестве такие незаменимые для организма человека аминокислоты, как лизин и триптофан [8].

Установлено, что в 1 кг зерна сахарной кукурузы в молочной спелости содержится: протеина - до 25 г, масла - до 8 г, углеводов - до 135 г, фосфора - до 775 мг, кальция - до 60 мг, железа - до 3,2 мг. Кроме того, она содержит большое количество таких витаминов, как тиамин (витамин $\mathrm{B}_{1}$ ) - до 100 мг, ниацин (витамин РР) - 11 мг, рибофлавин (витамин $\mathrm{B}_{2}$ ) - 0,76 мг, аскорбиновую кислоту (витамин С) - 65 мг, каротин и другие. При консервировании зерна количество витаминов почти полностью сохраняется [8].

Анализ последних исследований и публикаций по данной проблеме. Сахарная кукуруза возделывается преимущественно в Степи Украины, где сосредоточены ее основные посевные площади и норма потребления ее населением значительно выше, чем в других областях. В последние годы сахарная кукуруза пользуется большим спросом у населения нашей страны. Для возрастающего удовлетворения потребности на- селения необходимо увеличить производство и расширить посевные площади под сахарной кукурузой.

В последние годы сахарная кукуруза все больше встречается в производственных посевах, на общественных огородах и приусадебных участках. Несмотря на это, производственные посевы сахарной кукурузы ещё ограничены, а сортимент ее крайне беден. Незначительное распространение сахарной кукурузы является результатом недостаточного знания ее биологии и агротехники выращивания [9].

По своим биологическим особенностям сахарная кукуруза вполне пригодна для выращивания в зоне Степи Украины. Здесь производство сахарной кукурузы вполне возможно и рентабельно при внедрении эффективной технологии выращивания. К важным элементам агротехники надо отнести рациональное применение удобрений, регуляторов роста, биопрепаратов $[4,6]$. Значительную роль среди них играют микробиологические препараты для усиления фиксации азота из воздуха и мобилизации фосфорных соединений в почве, поскольку за счет этого расходы минеральных удобрений уменьшаются и повышается реализация генетического потенциала растений [5].

Самым распространенным способом внесения микробиологических препаратов является обработка семян (инокуляция). При наличии разных препаратов можно получить их смеси, в случае применения которых имеет место синэнергетический эффект. Используя такие смеси, есть возможность уменьшить дозы удобрений или количество обработок и тем самым ослабить экологическую нагрузку. Стимуляция роста растений длится непосредственно за счет синтеза регуляторов роста, органических кислот, витаминов или вытеснением патогенных микроорганизмов из ризосферы корней [7]. Таким образом, мы получаем одновременные всходы, которые крайне редки в гибридах сахарной кукурузы.

Азотфиксирующий потенциал во взаимодействии зерна кукурузы с имеющимися в почве формами имеет невысокую активность и недостаточ- 
ное их количество в зоне прорастания семян. За счет улучшения азотфиксации свободно существующих бактерий возможно улучшить баланс азота, уменьшить объемы использования минерального азота и существенно повысить урожайность початков сахарной кукурузы $[5,8]$.

Особенного внимания заслуживают исследования по биологизации питания сахарной кукурузы фосфором [4]. За счет биологических препаратов труднорастворимые органические и минеральные соединения фосфора трансформируются в формы, которые легко усваиваются растениями.

Цели исследований - установить особенности формирования урожайности гибридов сахарной кукурузы под воздействием комбинации различных видов биологических препаратов в условиях Степи Украины.

Задачи исследований - показать результаты практических опытов влияния различных видов микробиологических препаратов и их комбинаций на рост, развитие, урожайность и качество гибридов сахарной кукурузы; сделать выводы и дать предложения по применению биопрепаратов, исходя из проведенных исследований.

Объекты, методика и условия проведения исследований. Объектом исследования были три гибрида сахарной кукурузы: простой междулинейный сверхраннеспелый гибрид Арктур, простой междулинейный раннеспелый гибрид Спокуса, трехлинейный среднеранний гибрид Конкурент.

Оригинаторы: Институт сельского хозяйства степной зоны НААН Украины, Синельниковская селекционно-опытная станция ИСХСЗ НААН Украины [3].

На фоне гибридов изучали бактериальные препараты «Диазофит», «КЛ-9», биокомплекс («Диазофит» + «Фосфоэнтерин») для обработки семян непосредственно перед посевом.

Препараты «Диазофит» и «КЛ-9» способствуют накоплению азота и распределению его на протяжении вегетационного периода растений сахарной кукурузы, а «Фосфоэнтерин» - использованию неусвоенных предшественником фосфорных и труднодоступных фосфатов почвы, который дает возможность более полно реализовать потенциал гибридов, улучшить качество зерна. Исследования проводили в 2013-2014 гг. на кафедре технологий производства и профессионального образования Луганского национального университета им. Тараса Шевченко и на полях фермерского хозяйства «Венера-2005» Ста- робельского района Луганской области, которые расположены в зоне Степи Украины.

Почвы опытных участков - чернозем обыкновенный среднегумусоаккумулятивный с содержанием гумуса в пахотном слое почвы - 3,8-4,2 $\%$ (по Тюрину), валового азота - 0,21-0,26\%, легкогидролизированного азота (по Корнфилду) - 105-150 мг/кг почвы, подвижного фосфора (по Чирикову) - 84-115 мг, обменного калия (по Чирикову) - 81-120 мг/кг почвы.

При проведении экспериментов, наблюдений и учета использовались общепринятые и специальные методические рекомендации по проведению полевых опытов $[1,2]$.

Предшественник кукурузы - пшеница озимая. Обработка почвы - лущение стерни лущильником ЛДГ-10 в два следа, вспашка на глубину 23$25 \mathrm{~cm}$, ранневесеннее боронование и предпосевная культивация на 7-8 см.

Высевали семена кукурузы 25-26 апреля сеялкой СУПН-8. Семена протравливали препаратом «Дерозал» за 2-3 недели до сева (1,5 л/т), а биологическими препаратами - обрабатывали в день посева.

Результаты исследований. Подготовка семян является важным и ответственным элементом агротехники сахарной кукурузы. Она оказывает существенное влияние на ускорение темпов развития растения. При выращивании сахарной кукурузы было установлено, что биопрепараты при ранней стадии развития растений оказывали существенное значение на темпы прироста. В дальнейшем, влияние препаратов существенно повлияло на высоту растений и листовую поверхность. Сравнительную оценку влияния биопрепаратов на рост гибридов сахарной кукурузы можно увидеть в таблице 1.

Особенно положительное действие было от обработки семян сахарной кукурузы «КЛ-9» и биокомплексом. После обработки семян «КЛ-9» в среднем площадь листьев на растении и высота растений характеризовались такими показателями: 2950-3095 см ${ }^{2}$ и 178-188 см, а в контроле они представляли 2810-3040 $\mathrm{cm}^{2}$ и 170-180 см соответственно.

После обработки биокомплексом площадь листьев на растении и высота растений характеризовались следующими показателями: 2970$3110 \mathrm{~cm}^{2}$ и 180-189 см соответственно.

Прирост массы одного растения за счет применения биопрепаратов в гибридах сахарной кукурузы Арктур представлял 11 \%, Спокуса - 14 \%, а у гибрида Конкурент - $16 \%$. 
СІЛЬСЬКЕ ГОСПОДАРСТВО. РОСЛИННИЦТВО

\section{1. Влияние биологических препаратов на высоту растений и площадь листовой поверхности сахарной кукурузы}

\begin{tabular}{|c|c|c|c|c|c|c|}
\hline \multirow{2}{*}{ Вариант } & \multicolumn{3}{|c|}{ Высота растений, см } & \multicolumn{3}{|c|}{$\begin{array}{c}\text { Площадь листовой поверхности одного } \\
\text { растения, } \text { см }^{2}\end{array}$} \\
\hline & 2013 г. & 2014 г. & среднее & 2013 г. & 2014 г. & среднее \\
\hline \multicolumn{7}{|c|}{ Арктур } \\
\hline Контроль & 165 & 175 & 170 & 2730 & 2890 & 2810 \\
\hline «Диазофит» & 166 & 176 & 171 & 2730 & 2890 & 2810 \\
\hline «КЛ-9» & 174 & 182 & 178 & 2900 & 3000 & 2950 \\
\hline $\begin{array}{c}\text { «Диазофит»+ } \\
\text { «Фосфоэнтерин» }\end{array}$ & 176 & 184 & 180 & 2920 & 3020 & 2970 \\
\hline \multicolumn{7}{|c|}{ Спокуса } \\
\hline Контроль & 170 & 180 & 175 & 2820 & 2900 & 2860 \\
\hline «Диазофит» & 172 & 180 & 176 & 2870 & 2890 & 2880 \\
\hline «КЛ-9»» & 178 & 184 & 181 & 3010 & 3030 & 3020 \\
\hline $\begin{array}{c}\text { «Диазофит»+ } \\
\text { «Фосфоэнтерин» }\end{array}$ & 180 & 186 & 183 & 3040 & 3100 & 3070 \\
\hline \multicolumn{7}{|c|}{ Конкурент } \\
\hline Контроль & 175 & 185 & 180 & 3000 & 3080 & 3040 \\
\hline «Диазофит» & 178 & 186 & 182 & 3010 & 3100 & 3055 \\
\hline «КЛ-9» & 185 & 191 & 188 & 3080 & 3110 & 3095 \\
\hline $\begin{array}{c}\text { «Диазофит»+ } \\
\text { «Фосфоэнтерин» }\end{array}$ & 186 & 192 & 189 & 3100 & 3120 & 3110 \\
\hline
\end{tabular}

В целом микробиологические препараты положительно влияли на структурные элементы урожая сахарной кукурузы. В годы проведения эксперимента увеличивались такие показатели, как величина початка, его диаметр, количество зерен, масса зерен в початке. Если в среднем за 20132014 гг. в гибриде сахарной кукурузы Арктур в контроле количество рядов зерна в початке составляло $15-16$, то в случае применения препаратов 16-17, в гибриде Спокуса - 16-17 и 17-18, а в гибриде Конкурент - 15-16 и 17-18 соответственно. В среднем на 6-9\% увеличивалось количество зерен в ряду. Гибриды сахарной кукурузы Арктур, Спокуса и Конкурент при одинаковых условиях обработки микроэлементами показали практически одинаковый потенциал увеличения урожайности, который зависел только от собственной генетики растения.

Наибольшее суммарное водопотребление было у растений сахарной кукурузы Конкурент - 2250 $2360 \mathrm{~m}^{3} /$ га. Эффективнее всех грунтовые запасы влаги использовал гибрид сахарной кукурузы Арктур. Коэффициент водопотребления у него представлял 2080-2190 м $3 /$ га, что на $7 \%$ меньше, чем у гибрида Конкурент. Средние показатели по водопотреблению занял гибрид сахарной кукурузы Спокуса. Среди биологических препаратов по это- му показателю лучшие результаты обеспечил «Диазофит» в посевах гибрида сахарной кукурузы Арктур, а биокомплекс - в посевах гибридов Спокуса и Конкурент. Рост и развитие растений сахарной кукурузы под действием биологических препаратов заметно изменялся, о чем свидетельствуют показатели урожайности початков (табл. 2).

Следует отметить, что среди гибридов сахарной кукурузы лучшим по урожайности был Конкурент. В среднем за годы изучения урожайность этого гибрида составляла 5,30-5,50 т/га, что на 0,12-0,22 т/га больше, чем у гибрида Спокуса и на 0,16-0,28 т/га больше, чем у гибрида Арктур. При применении биокомплекса «Диазофит» + «Фосфоэнтерин» урожайность сахарной кукурузы гибридов Арктур и Спокуса была практически одинаковой. Среди микробиологических препаратов лучшим был «КЛ-9» и биокомплекс. Безусловно, рост урожайности является следствием улучшения условий питания и более ранних и одновременных всходов сахарной кукурузы, о чем свидетельствуют запасы питательных веществ в почве и растениях. В 2013 г. на контрольных площадях под конец уборки сахарной кукурузы 1 кг почвы содержал нитратного азота 6,6 мг, а при внесении «КЛ-9» - 8,7 мг, «Диазофита» - 10,5 мг, биокомплекса - 10,7 мг; в 2014 году $-6,5 ; 6,9 ; 8,3 ; 6,5$ мг соответственно. 
2. Урожайность кондиционных початков сахарной кукурузы в зависимости от действия биологических препаратов, $\mathrm{m} / 2 \mathrm{a}$

\begin{tabular}{|c|c|c|c|c|c|c|c|c|c|}
\hline \multirow{2}{*}{$\begin{array}{c}\text { Название } \\
\text { препаратов }\end{array}$} & \multicolumn{9}{|c|}{ Урожайность гибридов по годам, т/га } \\
\cline { 2 - 12 } & \multicolumn{3}{|c|}{ Арктур } & \multicolumn{3}{c|}{ Спокуса } & \multicolumn{3}{c|}{ Конкурент } \\
\cline { 2 - 12 } & 2013 & 2014 & сред. & 2013 & 2014 & сред. & 2013 & 2014 & сред. \\
\hline Контроль & 4,45 & 4,55 & 4,50 & 4,71 & 4,81 & 4,76 & 4,87 & 4,97 & 4,92 \\
\hline «Диазофит» & 4,61 & 4,77 & 4,69 & 4,91 & 5,01 & 4,96 & 5,00 & 5,10 & 5,05 \\
\hline «КЛ-9» & 4,81 & 4,99 & 4,90 & 5,00 & 5,10 & 5,05 & 5,10 & 5,30 & 5,20 \\
\hline $\begin{array}{c}\text { «Диазофит»+ } \\
\text { «Фосфоэнтерин» }\end{array}$ & 5,14 & 5,22 & 5,18 & 5,18 & 5,28 & 5,23 & 5,30 & 5,50 & 5,40 \\
\hline
\end{tabular}

Вывод. Таким образом, обработка семян сахарной кукурузы биопрепаратами «Диазофит», «КЛ-9», «Фосфоэнтерин» и комплексом «Диазофит» + «Фосфоэнтерин» активирует почвенную микрофлору, способствует мобилизации и оптимизации питания растений кукурузы азотом и фосфором, улучшению у них ростовых процессов, формированию высокой урожайности почат-

\section{БИБЛИОГРАФИЯ}

1. Доспехов Б. А. Методика полевого опыта / Б. А. Доспехов. - М. : Агропромиздат, 1986. $351 \mathrm{c}$.

2. Основы опытного дела в растениеводстве / [Ещенко В. Е., Трифонова М. Ф., Копытко П. Г. и др.]. - М. : Колос, 2009. - 268 с.

3. Каталог сортів та гібридів. ДУ Інститут сільського господарства степової зони НААН України / [Черенков А. В., Черчель В. Ю., Шевченко М. С. та ін.]. - Дніпропетровськ : «Роял Принт», 2014. - 104 с.

4. Носко Б. С. Сучасний стан та перспективні напрямки досліджень в агрохімії / Б. С. Носко // Вісн. аграр. науки. - 2002. - №9. - С. 9-12.

5. Патыка В. Ф. Агроэкологическая роль азотфиксирующих микроорганизмов / В. Ф. Патыка. - ков и улучшению качества зерна.

В связи с улучшением условий питания растений сахарной кукурузы всходы были получены более ранние и одновременные. Это способствовало дружному созреванию початков. Поэтому кратность уборки снизилась до двух раз, а продолжительность уборки уменьшилась.

K., 2004. $-320 \mathrm{c}$.

6. Ситник В. П. Екологічні аспекти агропромислового комплексу / В. П. Ситник // Вісник аграрної науки. - 2002. - №9. - С. 55-57.

7. Томакова Л. М. Мікробіологічні препарати на основі фосфат мобілізуючих мікроорганізмів у землеробстві / Л. М. Томакова // Пропозиція. 2006. - №9. - С. 68-70.

8. Циков В. С. Кукуруза на пищевые и лекарственные цели: производство, использование / В. С. Циков, Н. И. Конопля, С. В. Маслиёв. Луганск : «Шико», ООО «Виртуальная реальность», 2013. - $232 \mathrm{c.}$

9. Шмараев Г. Е. Сахарная кукуруза / Г. Е. Шмараев. - Л. : Колос, 1970. - 52 с. 